\title{
The First Histological Analysis of the Tissues Lining the Fossa Navicularis: Insights to its Etiology
}

Sarvenaz Sheikh ${ }^{1}$, Joe Iwanaga ${ }^{2}$, Steven Rostad ${ }^{3}$, Tarush Rustagi ${ }^{4}$, Rod J. Oskouian ${ }^{5}$, R. Shane Tubbs 6

1. Seattle Science Foundation 2. Medical Education and Simulation, Seattle Science Foundation, Seattle, USA 3. Pathology, CellNetix 4. Swedish Neuroscience Institute, Swedish Medical Center 5. Neurosurgery, Swedish Neuroscience Institute, Seattle, USA 6. Neurosurgery, Seattle Science Foundation, Seattle, USA

$\square$ Corresponding author: Joe Iwanaga, joei@seattlesciencefoundation.org Disclosures can be found in Additional Information at the end of the article

\section{Abstract}

The fossa navicularis (FN) is an anatomical variant on the ventral surface of the basilar part of the occipital bone that, to date, has only been investigated in bone specimens. We aim to clarify the structure of the fossa navicularis by gross anatomical, radiological, and histological methods. The FN was found in the occipital bone of the Caucasian male cadaver. There was no bony or histological continuity between the FN and posterior cranial fossa. The histological analysis found that the overlying tissue was composed of loose connective tissue with a mixture of collagen and elastic fibers and a vascular matrix including arteries, veins, and capillaries. There was no evidence of lymphoid, glandular, or notochordal tissues. As no previous studies have performed histological analysis of the FN, this report adds to our knowledge of tissues that are involved in its formation.

\section{Categories: Neurosurgery, Orthopedics}

Keywords: occipital bone, clivus, anatomy, histology, computed tomography, notochord, fossa navicularis

\section{Introduction}

The fossa navicularis (FN) is a small round depression [1] located on the ventral surface of the basilar part of the occipital bone and superior to the pharyngeal tubercle. Studies of this structure using a dry skull and computed tomography (CT) have been reported [2]. The etiology of these depressions has only been speculated until date. For example, some authors have posited that this fossa could be filled with nasopharyngeal tonsillar tissue [2-4]. However, to our

Received 05/11/2017 Review began 05/17/2017 Review ended 05/26/2017 Published 05/31/2017

\section{(c) Copyright 2017}

Sheikh et al. This is an open access article distributed under the terms of the Creative Commons Attribution License CC-BY 3.0., which permits unrestricted use, distribution, and reproduction in any medium, provided the original author and source are credited. knowledge, none of the previous studies has performed histological observation of the contents of the FN. Therefore, we aimed to further elucidate an incidentally found FN by gross anatomical, radiological, and histological methods.

\section{Case Presentation}

The FN was found in the occipital bone of a Caucasian male cadaver (74 years old at death) that was examined with CT before routine gross anatomy dissection (Figure 1). 


\section{Cureus}

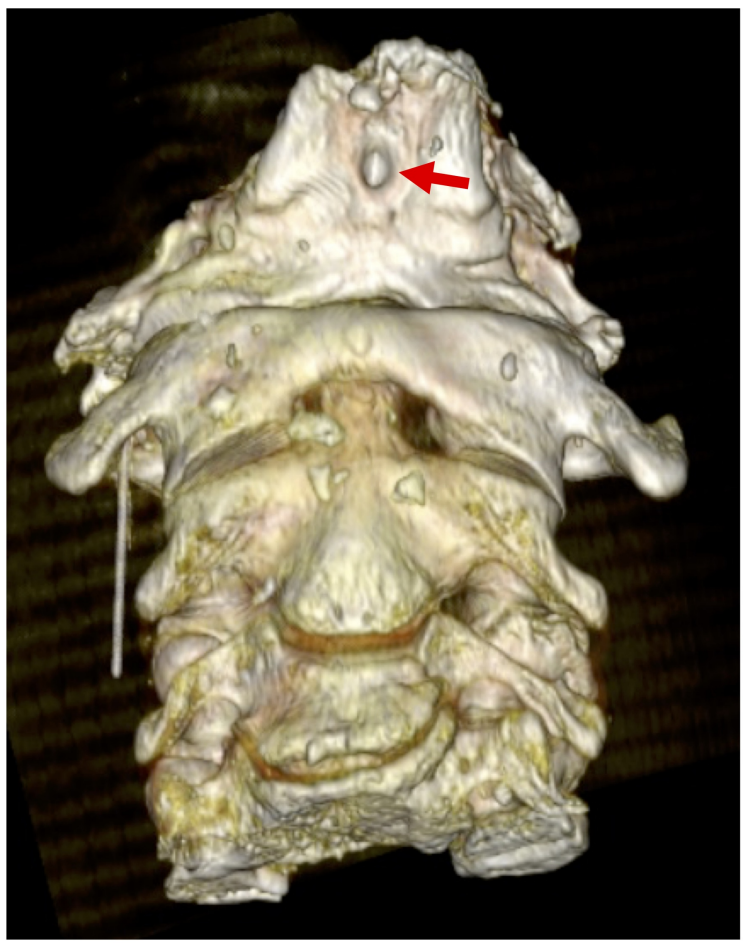

FIGURE 1: Anterior view of the fossa navicularis (arrow) as seen via 3D-CT.

3D-CT: three-dimensional computed tomography

CT revealed a shallow concavity on the ventral surface of the occipital part of the clivus, which was located in the midline and anterosuperior to the pharyngeal tubercle. The FN was $4.5 \mathrm{~mm}$ in length, $2.5 \mathrm{~mm}$ in width, and $2.0 \mathrm{~mm}$ in depth (Figure 2).
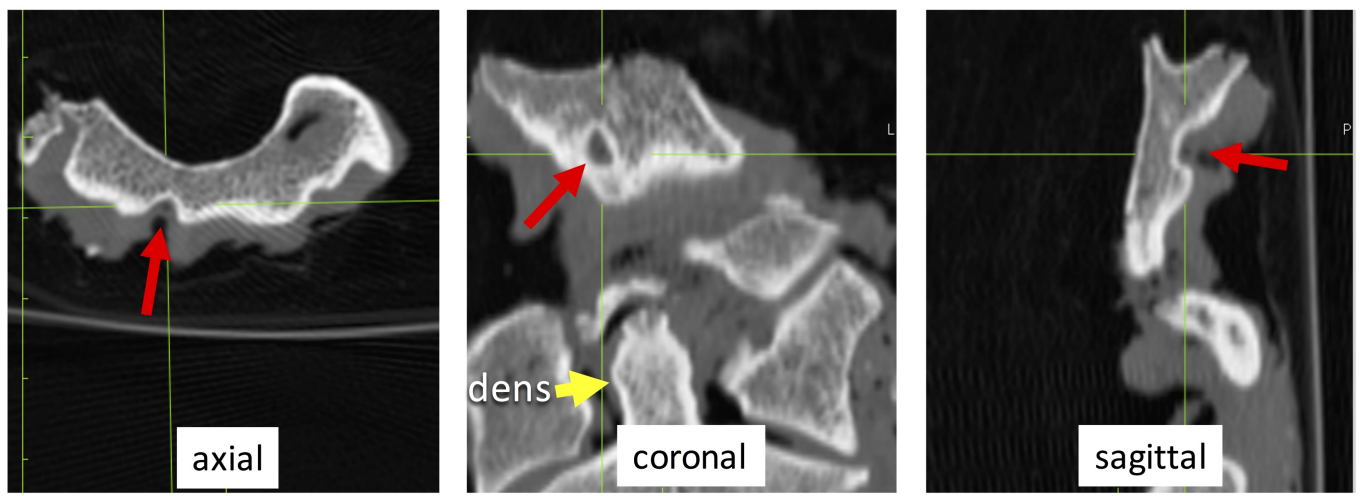

FIGURE 2: Cross section computed tomography (CT) of the fossa navicularis (red arrow)

There was no continuity between the FN and the posterior cranial fossa. Next, the overlying soft tissues and tissues invaginating and lining the FN were observed and dissected using a surgical 


\section{Cureus}

microscope (OPMI CS NC31) (Carl Zeiss, Oberkochen, Germany). No specific structure(s) (e.g., grossly identifiable blood vessels, glands, adipose tissue, cysts, etc.) was found inside or around the fossa (Figure 3).

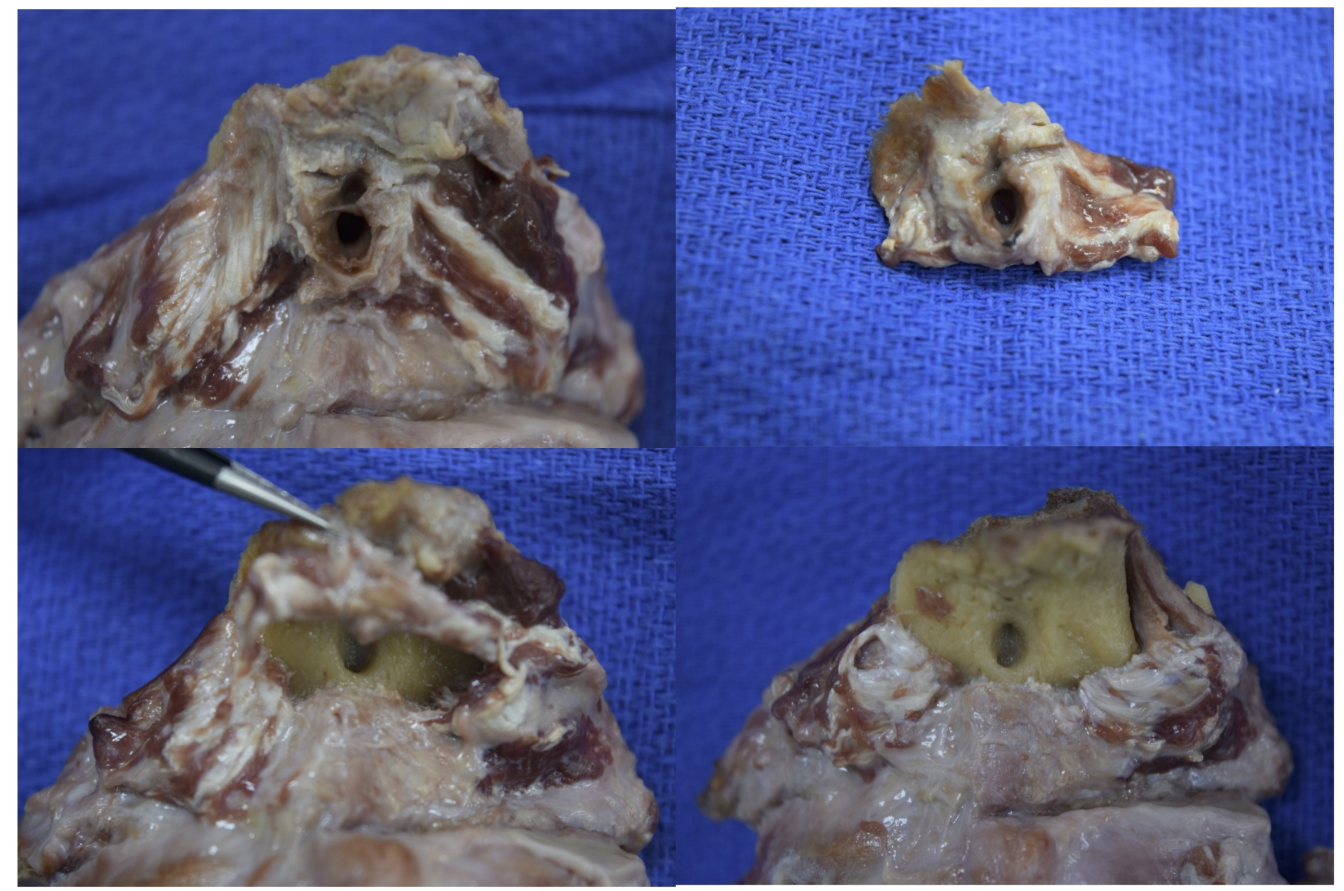

FIGURE 3: Gross observation of the fossa navicularis

The soft tissues filling the FN were removed and submitted for histological examination. Hematoxylin and eosin (H\&E) stain showed non-specific collagenous and elastic fibers making up the tissue lining. Masson-trichrome stain, elastic fiber stain, and periodic acid-Schiff stain (PAS) showed the superficial part of the overlying tissue, which lay on the fossa, was composed of loose connective tissue with a mixture of collagen and elastic fibers and a vascular matrix including arteries, veins, and capillaries. Less vasculature tissue and elastic fibers filled with collagen fibers were found in the surrounding tissues of the fossa (Figure 4). 


\section{Cureus}
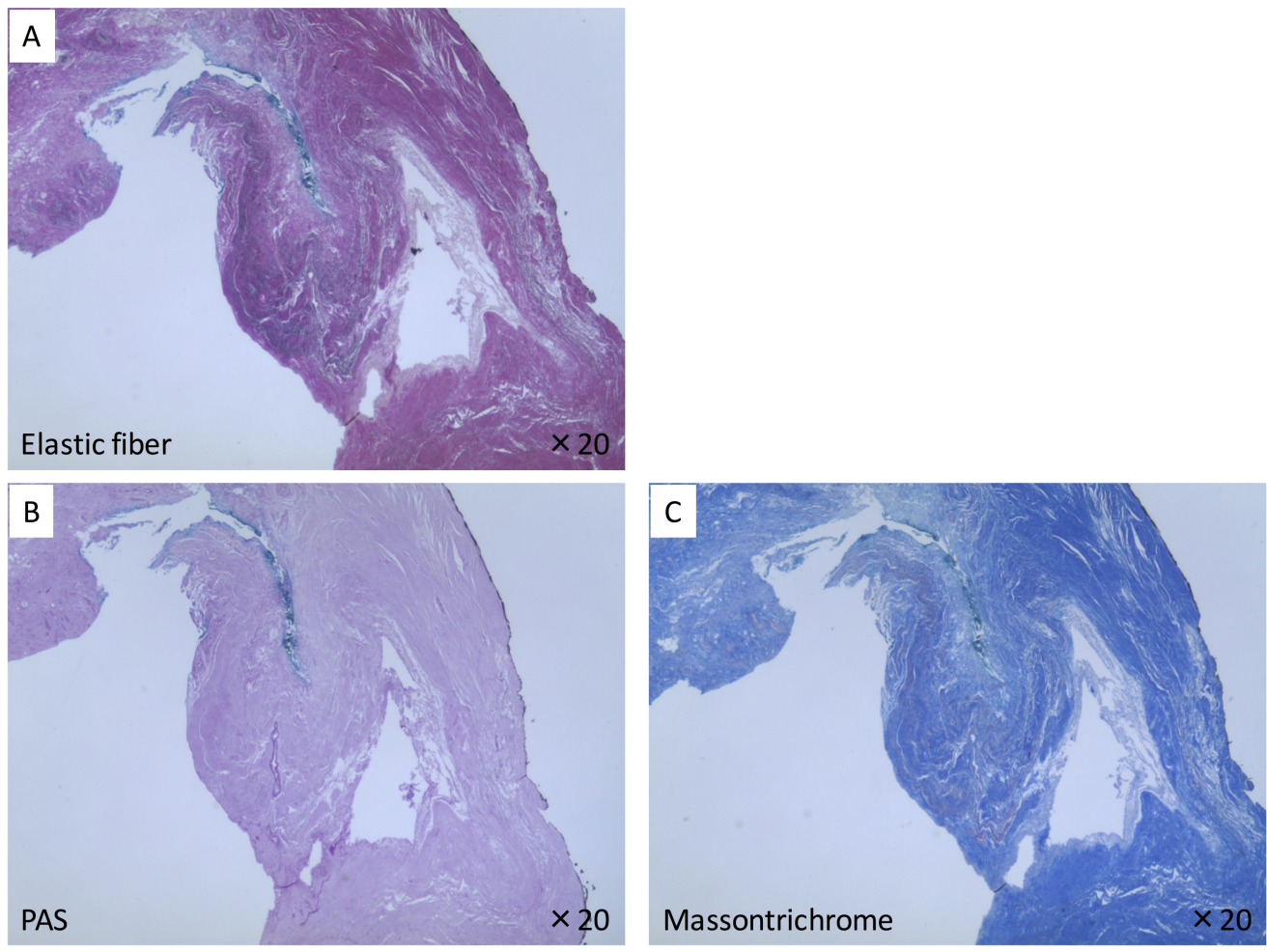

FIGURE 4: Histological analysis of the soft tissue filling the fossa navicularis.

A) Elastic fiber stain; B) periodic acid-Schiff stain; C) Masson's trichrome stain

There was no evidence of the lymphoid or glandular tissue in any of the histologically analyzed tissues.

\section{Discussion}

The FN has been termed by various authors as the fossa navicularis magna, medial basal fossa, fossa pharyngea, large pharyngeal fossa, canalis basilaris medianus, keyhole defect, and longitudinal or transverse segmentation defects [1]. Of them all, our literature review found that the FN has been used most frequently with some making distinctions between the FN and the median basal canal [2, 4-5]. According to Currarino [5], the FN is a rare anatomic variant of the basiocciput and is a subtype of the canalis basilaris medianus (CBM) [6]. This author referred to the FN as an incomplete form of the CBM.

The prevalence of the $\mathrm{FN}$ is reported from 0.9 to $5.3 \%$ and measurements vary from $1.1 \mathrm{~mm}$ to $5.5 \mathrm{~mm}$ in depth, $1.79 \mathrm{~mm}$ to $13 \mathrm{~mm}$ in length, and $1.5 \mathrm{~mm}$ to $8 \mathrm{~mm}$ in width [2, 7-9]. According to Cankal, et al., 2.9\% (14/492) of dry human skulls had an FN of greater than or equal to $2 \mathrm{~mm}$ in depth and an FN was identified in $3.0 \%(16 / 525)$ of patients on CT [2].

Generally, two theories have been suggested concerning the embryology of the FN. One theory suggests that all canals and foramina seen on the surface of the basiocciput are vascular in origin and are similar to the basivertebral foramina of the vertebral bodies [8]. However, another theory suggests that the FN represents remnants of the cephalic end of the notochordal canal [9]. According to Staderini [9], the CBM bifurcates have a double origin, the 
superior canal is vascular in origin and the rest of the defect is related to the notochordal canal. Histological findings of the present case demonstrated that the tissue lining the FN was composed of loose connective tissue with a mixture of collagen and elastic fibers and a vascular matrix. The existence of the vascular matrix might support the former theory of the embryology but does not support a notochordal etiology for the development of the FN. In addition, several MRI studies have described the FN as being filled with lymphoid tissue of the nasopharyngeal tonsils but have made these comments without histology [2-4]. Our study showed soft tissue in the fossa but no lymphoid tissue was found within it.

From the clinical perspective, the differential diagnosis of the FN should include local or metastatic tumor, adenoid retention cyst, Rathke's pouch cyst, adenoid hypertrophy, and Tornwaldt's cyst $[2,4]$. Knowledge of this bony variation might promote a better diagnosis of diseases in this region [2].

\section{Conclusions}

Review of literature did not show any histological observation of the FN and such analysis offers an interesting window into the true nature of tissues related to this bony depression. Further studies with histological analysis might help better clarify the structure of the FN in a larger series of specimens.

\section{Additional Information \\ Disclosures}

Human subjects: Consent was obtained by all participants in this study. Conflicts of interest: In compliance with the ICMJE uniform disclosure form, all authors declare the following: Payment/services info: All authors have declared that no financial support was received from any organization for the submitted work. Financial relationships: All authors have declared that they have no financial relationships at present or within the previous three years with any organizations that might have an interest in the submitted work. Other relationships: All authors have declared that there are no other relationships or activities that could appear to have influenced the submitted work.

\section{Acknowledgements}

The author thanks those who donated their bodies for anatomical research.

\section{References}

1. Syed AZ, Mupparapu M: Fossa navicularis magna detection on cone-beam computed tomography. Imaging Sci Dent. 2016, 46:47-51. 10.5624/isd.2016.46.1.47

2. Jacquemin C, Bosley TM, al Saleh M, Mullaney P: Canalis basilaris medianus: MRI. Neuroradiology. 2000, 42:121-23. 10.1007/s002340050029

3. Marom T, Russo E, Ben Salem D, Roth Y: Nasopharyngeal cysts. Int J Pediatr Otorhinolaryngol. 2009, 73:1063-70. 10.1016/j.ijporl.2009.01.004

4. Cankal F, Ugur HC, Tekdemir I, Elhan A, Karahan T, Sevim A: Fossa navicularis: Anatomic variation at the skull base. Clin Anat. 2004, 17:118-22. 10.1002/ca.10191

5. Currarino G: Canalis basilaris medianus and related defects of the basiocciput . AJNR Am J Neuroradiol. 1988, 9:208-11.

6. Hauser G, De Stefano GF: Epigenetic Variants of the Human Skull. Schweizerbart Science Publishers, Stuttgart, Germany; 1989.

7. Beltramello A, Puppini G, El-Dalati G, Girelli M, Cerini R, Sbarbati A, Pacini P: Fossa navicularis magna. AJNR Am J Neuroradiol. 1998, 19:1796-98.

8. Fiegler $\mathrm{W}$ : The canalis basilaris medianus on the $\mathrm{x}$-ray and computed tomogram (author's transl) (Article in German). Rofo. 1980, 133:416-19. 10.1055/s-2008-1056755 


\section{Cureus}

9. Staderini R: Median basal canal and its morphological significance (Article in Italian) . Monitore Zool Ital. 1900, 11:131-37. 